\title{
EFFECT OF BADMINTON SHOE SOLE ON THE LUNGE SKILL PERFORMANCE: IN THE VIEWPOINT OF COORDINATION
}

\author{
Guanchun $\mathrm{LIU}^{1}$, Yuqi $\mathrm{LI}^{2}$, Quting HUANG ${ }^{2}$, Jin $\mathrm{ZHOU}^{1,2} *$, Wing-Kai LAM ${ }^{3} *$ \\ ${ }^{1}$ College of Electronics and Information, Sichuan University, Intelligent Control Institute, Chengdu 610065, China, \\ $552750014 @ q q . c o m$
}

${ }^{2}$ National Engineering Laboratory for Clean Technology of Leather Manufacture, Sichuan University, Chengdu 610065, China, zj_scu@scu.edu.cn

${ }^{3}$ Li Ning Sports Science Research Center, Li Ning (China) Sports Goods Company, Beijing 101111, China, gilbertlam@lining.com.cn

\section{EFFECT OF BADMINTON SHOE'S SOLE ON THE LUNGE SKILL PERFORMANCE: IN THE VIEWPOINT OF COORDINATION}

ABSTRACT. Badminton lunge requires rapid coordination between the knee and ankle joints and it is accompanied by fast contact between the shoe's sole and the floor. Phase angle analysis is a protocol with high resolution and relating to the coordination, but how the shoe's sole would affect the lunge performance was not clear in terms of coordination. Thereby, the aim of this study was to applied phase angle analysis to insight the lunge process, then to disclose the effect of badminton shoe's sole on the lunge skill performance. Eleven elite badminton players performed five left-forward maximum lunge trials with wearing Rounded Heel Shoe (RHS), Flattened Heel Shoe (FHS), and Standard Heel Shoes (SHS). The motion capturing system was used to measure the knee and ankle kinematics information. The Phase Angle (PA), continuous relative phase (CRP) and variability of continuous relative phase (VCRP) between the knee and ankle joints were then calculated for both forward lunge phase and recovery phase in each of the three shoes. Current findings indicated that players wearing RHS had certain advantages on better movement coordination than other shoes, as indicated by better PA and CRP. The findings of this study would be helpful to understand the coordination of badminton lunges and explain the synergy between the lower extremity ankle and knee joint to minimize the possibility of injury in badminton. Furthermore, the coordination between the knee and ankle joints was greatly affected by the structure of the shoe heel design.

KEY WORDS: phase angle, kinematics, coupling angle, lunging, footwear, badminton shoe

\section{INFLUENȚA TĂLPII PANTOFILOR DE BADMINTON ASUPRA EXECUTĂRII FANDĂRILOR ÎN CEEA CE PRIVEȘTE COORDONAREA}

REZUMAT. Fandările în badminton necesită o coordonare rapidă între articulațiile genunchiului și ale gleznei, însoțită de un contact rapid între talpa pantofului și podea. Analiza unghiului de fază este un protocol de înaltă rezoluție care se referă la coordonare, dar nu este clar modul în care talpa pantofului afectează executarea fandării în ceea ce privește coordonarea. Prin urmare, scopul acestui studiu a fost de a aplica analiza unghiului de fază pentru a studia procesul de executare a fandării, apoi de a dezvălui influența tălpii pantofului de badminton asupra executării fandării. Unsprezece jucători de badminton de elită au executat cinci fandări cu extensie maximă, cu piciorul stâng înainte, purtând pantofi cu toc rotunjit (RHS), pantofi cu toc aplatizat (FHS) și pantofi cu toc standard (SHS). Sistemul de captare a mișcării a fost utilizat pentru a măsura datele cinematice ale genunchiului și ale gleznei. Unghiul de fază (PA), faza relativă continuă (CRP) și variabilitatea fazei relative continue (VCRP) între articulațiile genunchiului și ale gleznei au fost apoi calculate atât pentru faza de fandare înainte, cât și pentru faza de recuperare, pentru fiecare dintre cele trei tipuri de pantofi. Descoperirile actuale au indicat faptul că jucătorii care au purtat pantofii tip RHS au avut anumite avantaje în ceea ce privește o mai bună coordonare a mișcării decât cei care au purtat alt tip de pantofi, după cum indică valorile PA și CRP mai bune. Rezultatele acestui studiu ar fi utile pentru a înțelege coordonarea fandărilor în badminton și pentru a explica sinergia dintre extremitatea inferioară a gleznei și articulația genunchiului pentru a reduce la minim posibilitatea rănirii practicând badminton. În plus, coordonarea dintre articulațiile genunchiului și ale gleznei a fost foarte afectată de designul tocului pantofului.

CUVINTE CHEIE: unghi de fază, cinematică, unghi de cuplare, fandare, încălțăminte, pantof de badminton

\section{L'EFFET DE LA SEMELLE DE LA CHAUSSURE DE BADMINTON SUR L'EXÉCUTION DE LA FENTE, EN TERMES DE COORDINATION}

RÉSUMÉ. La fente de badminton nécessite une coordination rapide entre les articulations du genou et de la cheville et s'accompagne d'un contact rapide entre la semelle de la chaussure et le sol. L'analyse de l'angle de phase est un protocole à haute résolution et relatif à la coordination, mais la façon dont la semelle de la chaussure affecte l'exécution de la fente n'est pas claire en termes de coordination. Ainsi, le but de cette étude était d'appliquer une analyse d'angle de phase pour comprendre le processus de fente, puis de révéler l'effet de la semelle de la chaussure de badminton sur l'exécution de la fente. Onze joueurs de badminton d'élite ont effectué cinq extensions maximales avec leur pied gauche en avant, en portant des chaussures à talons arrondis (RHS), des chaussures à talons plats (FHS) et des chaussures à talons standard (SHS). Le système de capture de mouvement a été utilisé pour mesurer les informations cinématiques du genou et de la cheville. L'angle de phase (PA), la phase relative continue (CRP) et la variabilité de la phase relative continue (VCRP) entre les articulations du genou et de la cheville ont ensuite été calculés pour la phase de fente avant et la phase de récupération pour chacun des

\footnotetext{
* Correspondence to: Assoc. Prof. Jin ZHOU, National Engineering Laboratory for Clean Technology of Leather Manufacture, Sichuan University, Chengdu 610065, P. R. China; (zj_scu@scu.edu.cn) and Mr. Wing-Kai LAM, Li Ning Sports Science Research Center, Li Ning (China) Sports Goods Company, Beijing 101111, China (gilbertlam@li-ning.com.cn)
} 
trois types de chaussures. Les résultats actuels ont indiqué que les joueurs portant des chaussures type RHS avaient certains avantages sur une meilleure coordination des mouvements en comparaison avec les autres types de chaussures, comme indiqué par de meilleures valeurs PA et CRP. Les résultats de cette étude seraient utiles pour comprendre la coordination des fentes de badminton et expliquer la synergie entre l'extrémité inférieure de la cheville et l'articulation du genou afin de minimiser la possibilité de blessure en jouant au badminton. De plus, la coordination entre les articulations du genou et de la cheville était grandement affectée par la structure de la conception du talon de la chaussure.

MOTS CLÉS : angle de phase, cinématique, angle d'accouplement, fente, chaussure, chaussure de badminton

\section{INTRODUCTION}

Badminton is considered as one of the fastest racket sports in the world [1], which requires excellent strength, dynamic balance, quick response and body coordination [2, 3]. Lunge is a frequently executed footwork in badminton, which consists of simultaneously stretch and retraction of the hip, knee, and ankle joints through muscular strength and power [4]. This movement requires a high level of coordination in a very short time between points $[2,5]$. During lunges, badminton players may be exposed to the strenuous impacts, accounting for more likelihood of badminton injury [6]. Studying joint contact can predict injury in badminton [7].

To date, research has reported that the knee and ankle joints were the most frequently injured joints in badminton players $[12,13]$. Reeves et al. [12] concluded that the knee could be exposed to higher risk of injuries whilst performing strenuous turns or cuts that predominantly occur in the frontal and transverse planes instead of the sagittal plane alone. The authors suggested that studying sport specific movements could better analyze the underlying mechanisms of lower limb injury. Huang et al. [14] maximized the jerk motion of badminton players using an injury mechanism model and they found that professional badminton players showed a large knee joint torque in both sagittal and frontal planes. According to the study of Herbaut et al. [13], the greater the degree of ankle inversion, the more likelihood of ankle sprain injury can be found. Wang et al. [15] reported that the net joint torque was closely related to the co-contraction levels between agonist and antagonist muscles during isokinetic ankle dorsiflexion.
In addition, Phomsoupha et al. [3] suggested that badminton sports required high performance of badminton shoes especially during the landing phase of a lunge. Appropriate shoes would improve the performance and attenuate impact forces effectively during a lunge. For instance, Kesilmiş et al. [16] found that the athletes wearing Kangoo Jump Shoes can improve dynamic balance and muscle strength at ankle joint. Similarly, changing the heel curvature design in badminton shoes could reduce ground reaction forces and knee moments during lunges, implying a lower risk of joint injury [6]. As the key interface between foot and ground, the shoe features would influence movement coordination during various sports.

Normally, although we could know how the lunge performed through kinematic in a joint, we lack details such as correlation within lower limb joints. Badminton lunge requires rapid coordination between the knee and ankle joints and it is accompanied by fast contact between the shoe's sole and the floor. Since coordination is considered as important to maintain the appropriate relationship between joint movements and muscle contractions, it ensures the efficiency of sport activities [8, 9]. Movement coordination is described as the capability to complete a series of actions accurately and smoothly, which is usually assessed by the continuous relative phase $[10,11]$. Therefore, to reduce the injury potential to joints and muscles during badminton exercises, it seems insightful to evaluate the coordination during extreme lunge to establish theoretical framework for badminton athletes. Unfortunately, how the shoe's sole would affect the lunge performance was not clear in terms of coordination.

Hence, the present study was aimed to apply phase angle analysis to insight the lunge 
process, then to disclose the effect of badminton shoe's sole on the lunge skill performance. Based on the existing literature, we hypothesized that different shoe soles would affect the coordination of the knee and ankle joints during lunge, especially during initial impact phase.

\section{METHODS}

\section{Participants}

Eleven male elite badminton players participated in this study with the mean age of $20.6 \pm 0.7$ years, mean body height of $156.0 \pm$ $6.0 \mathrm{~cm}$, mean body weight of $70.9 \pm 5.9 \mathrm{~kg}$, and mean year of playing experience of $8.4 \pm$ 1.4 years. All participants were right-handed and had experience of national game participation. They reported no lower limb injuries for at least six months prior to the test. Participants signed the written consent and all the procedures were confirmed with the principles of the Helsinki Declaration.

\section{Footwear Conditions}

Three identical pairs of badminton shoes with different modifications of heel shape were built for this study (Figure 1): Rounded Heel Shoe (RHS), Flattened Heel Shoe (FHS), and Standard Heel Shoe (SHS). As aligned with the previous study [6], the RHS was modified with the $5-\mathrm{mm}$ extension at the tip of the posterior heel with reference to the original professional badminton shoe model (Li Ning SAGA, Beijing, China). The FHS had a flat edge on the posterior heel. And the SHS was the original specification available in the market without any modification, which was used as a reference shoe condition for this study.

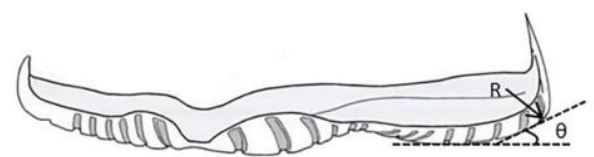

i) Rounded heel shoe

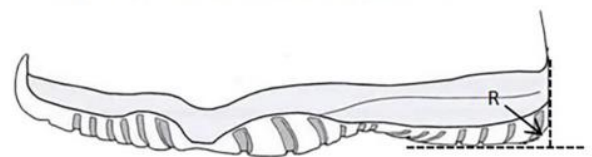

ii) Flatted heel shoe

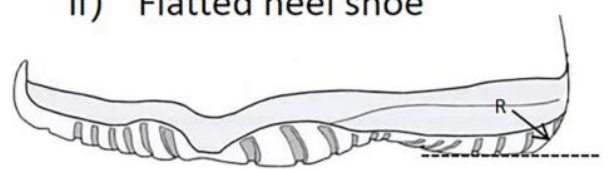

iii) Standard heel shoe

Figure 1. Footwear structure. (i) Rounded Heel Shoe, (ii) Flattened Heel Shoe, and (iii) Standard Heel Shoe

\section{Kinematics Measurement}

The lower limb kinematics data were obtained using an infrared motion system at $200 \mathrm{~Hz}$. Since left-forward direction was considered as a key direction in the badminton lunge study for its higher landing impact $[3,4,17]$, the lunging leg (i.e., right leg) information during maximum-effort lunge toward the left-forward direction were selected to assess the lower limb coordination. The cameras were arranged in a circle manner to capture all the marker trajectories during the entire lunge landing.

The athletes were asked to warm up and stretch in the test zone whilst wearing experimental shoes. Following the standard static and dynamic calibrations as specified from the manufacturer, the camera lens distortion was minimized for actual data collection. Then, the participants were instructed to perform five left-forward lunge trials with maximum-effort wearing each type of shoe in a randomized manner. The task was the lunge to the 45-degree toward the left from the individual starting position and then hit the suspended target. A complete test cycle was from initial heel contact, hitting the shuttlecock, and then recovery back to the original starting position. 


\section{Data Processing}

The marker trajectories were filtered by a fourth-order low-pass Butterworth with a cut-off frequency at $6 \mathrm{~Hz}$. Then, the data were normalized to 101 points with quintuple spline procedure. The ankle and knee angles were calculated and then determined the vector angles $(\theta)$ with respect to the horizontal in the sagittal plane for further analysis [18].

$\theta_{\text {centered }}\left(t_{i}\right)=\theta\left(t_{i}\right)-\min (\theta(t))-\frac{\max (\theta(t))-\min (\theta(t))}{2}$

$\zeta(\mathrm{t})=\theta_{\text {centered }}(t)+i H(t)$

$\varphi\left(t_{i}\right)=\tan ^{-1}\left(\frac{H\left(t_{i}\right)}{\theta_{\text {centered }}\left(t_{i}\right)}\right)$

$C R P_{(1-2)}\left(t_{i}\right)=\varphi_{1}\left(t_{i}\right)-\varphi_{2}\left(t_{i}\right)$

where $\theta_{\text {centered }}\left(t_{i}\right)$ and $\theta\left(t_{i}\right)$ represent the zerocentered and original Euler angles at each time point $\left(t_{i}\right) ; \min (\theta(t))$ and $\max (\theta(t))$ are the minimum and maximum values over these 100 points, respectively; $\mathrm{H}(t)$ of $\theta_{\text {centered }}\left(t_{i}\right)$ represents the Hilbert transform imaginary part of the analytic signal $\xi(t) ; \varphi_{1}\left(t_{i}\right)$ and $\varphi_{2}\left(t_{i}\right)$ serve as the phase angles of the proximal joint and the distal joint, respectively.

Firstly, the vector angles of each selected joints were transformed to the zero baseline (Eq. 1). Secondly, each zero-centered set of data was put into an analytic signal $(\xi(t))$ by Hilbert transform and obtained the imaginary part $\left(H\left(t_{i}\right)\right)$ (Eq. 2) [20]. Thirdly, the phase angle $\left(\varphi\left(t_{i}\right)\right)$ at each time point was calculated by substituting the required data into the formula (Eq. 3). Finally, continuous relative phase by subtracting the phase angles between the two joints (Eq. 4).

The CRP usually ranged between -180 and 180 degrees. Perfect in-phase indicated a value of 0 degree, representing the two joints rotated in the same direction; while perfect anti-phase was 180 degrees, representing the two joints rotating in opposite directions. Furthermore, the CRP between 0 and 180 degrees was classified as out-phase [11]. The phase of CRP showed the correlation between joint angles and velocities, providing a basis for assessing coordination of limb [10].
In this study, continuous relative phase (CRP) and variability of CRP (VCRP) were also calculated to identify the coordination between two adjacent joints. For CRP, the joint data were processed through Hilbert transform introduced by Lamb and Stöckl [19] to quantify the coordination without any artificial interference. The four main formulas were calculated as follows to determine CRP $[11,19,20]$.

Additionally, the variability of continuous relative phase (VCRP) was evaluated as the between-stride standard deviation for a single subject within the 101 data points, which aimed to evaluate the variability within joints [11]. The VCRP was considered as a valuable index to evaluate the motor coordination. The high value indicated a poor degree of coordination between the two joints [11].

\section{Statistical Analysis}

At first, since lunge movement would be finished in a very short time, both knee and ankle joint were in a status of flexion, the ankle plantar flexion and knee flexion were the target for further analysis.

All the CRP and VCRP data were averaged across groups. As for time series variables, GROUP ANALYSIS was performed with Model Statistic Procedure, which showed macro variations between different conditions in the lunge tasks [11]. Independent samples T-test indicated obvious exploring variation to explore detailed inter-group differences. We obtained 101 significant or insignificant results through statistical analysis in each group of time series data, and then accumulated the percentage of points $(\% \mathrm{P})$ to demonstrate the results of group analysis. Paired Student Ttests (ES>0.8) were performed to assess the 
credibility of the shoe comparison [4]. All statistical analysis was performed using SPSS ( $v 22.0$, IBM, USA) with a significance level at 0.05 .

\section{RESULTS}

\section{Phase Angle (PA) Variables}

The PA of ankle was indicated in Figure 2. In terms of lunging forward, ankle joint plantar flexed slightly faster when wearing

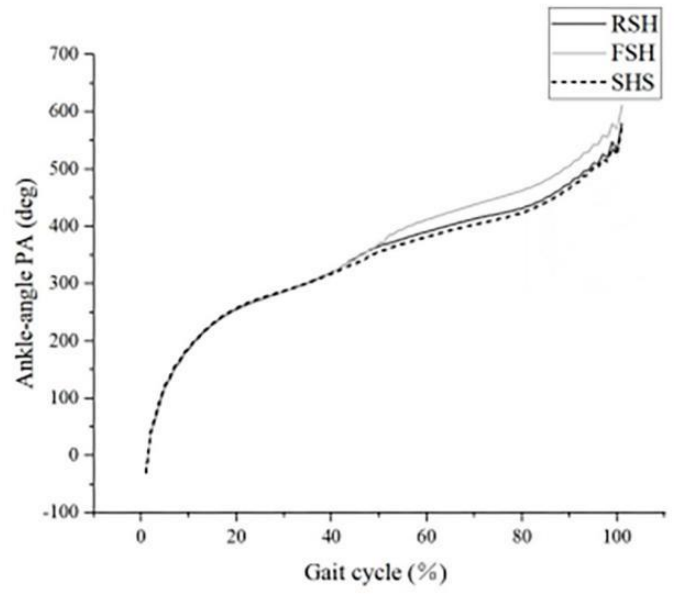

(a)

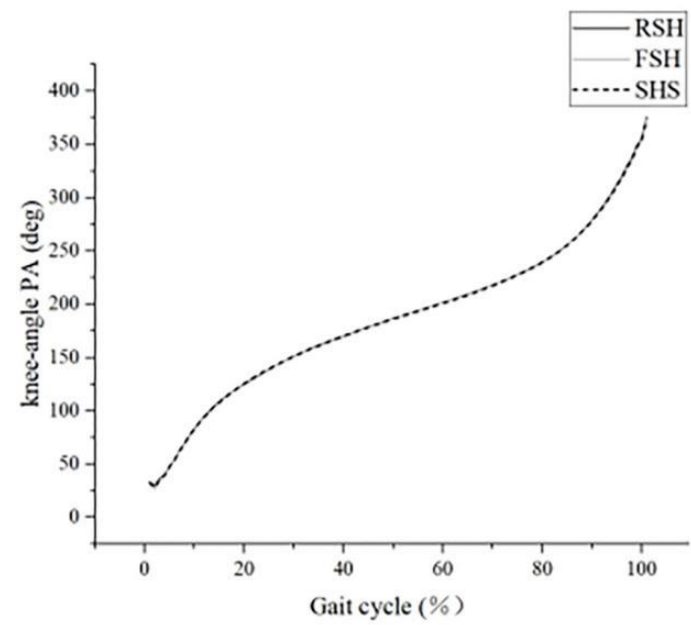

(c)
RSH and FSH since $30 \% \mathrm{GC}$; while plantar flexion of ankle with $\mathrm{FSH}$ was relatively higher than RSH since $48 \% \mathrm{GC}$ (Figure 2a). No significant differences were found for lunging backward (Figure 2b), as well as both lunging forward and backward in knee joint (Figure 2c, d).

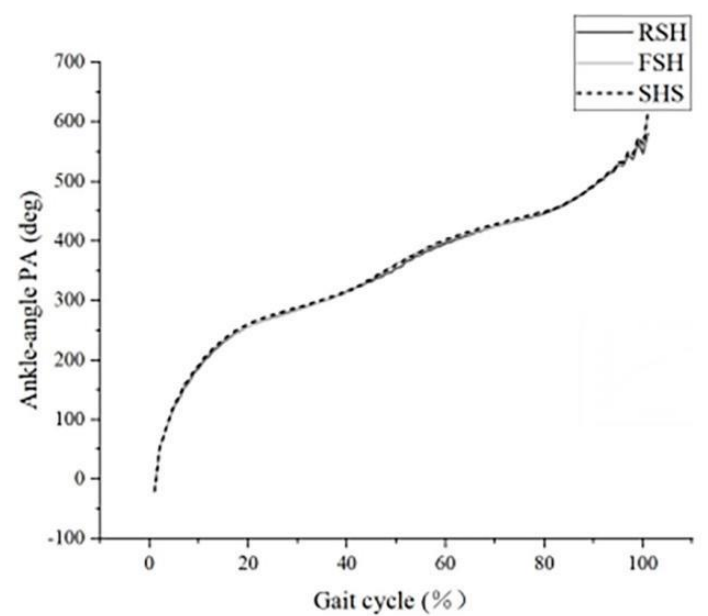

(b)

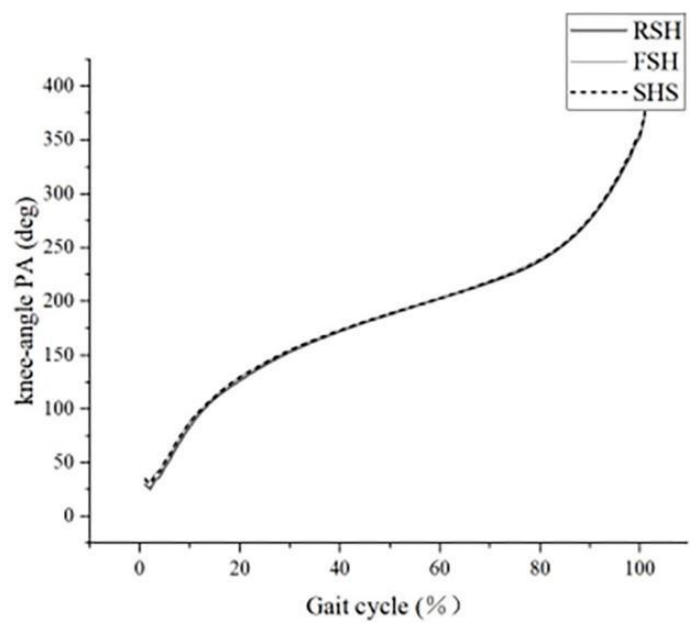

(d)

Figure 2. Phase angle (PA) curves for rounded heel shoe (RSH), flattened heel shoe (FHS), and standard heel shoe (SHS) over the gait cycle. Gait cycle (GC) duration was taken as the time interval between two successive heel strikes of one leg; (a) and (b) are about ankle angle of forward and backward respectively, (c) and (d) are about knee angle of forward and backward respectively.

\section{CRP Outcomes}

According to Figure $3 a$, there were noticeable changes in CRP trajectories of Knee-Ankle coupling at gait cycle among three kinds of tested shoes. When wearing RHS to perform lunging forward movement, a faster ankle plantar flexion than knee flexion was found since $30 \% \mathrm{GC}$; while similar relation was found in FHS since $60 \% \mathrm{GC}$. But there were few differences between SHS and RSH during recovery phase of lunge (Figure $3 b$ ). 


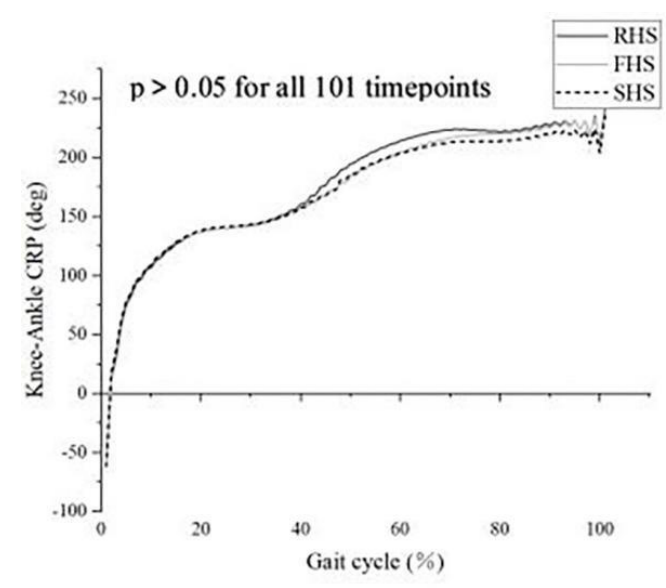

(a)

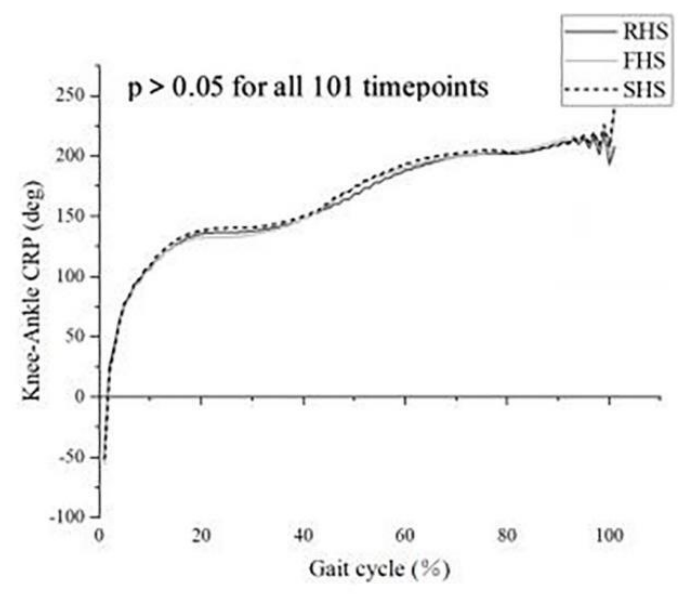

(b)

Figure 3. Continuous relative phase (CRP) curves of forward lunge (a) and recovery back to starting position (b) for rounded heel shoe (RSH), flattened heel shoe (FHS), and standard heel shoe (SHS) over the gait cycle. Gait cycle (GC) duration was taken as the time interval between two successive heel strikes of one leg

\section{VCRP Outcomes}

In terms of lunge forward, mean VCRP was 12.1 for RHS, 13.4 for FHS and 11.7 for SHS; while those in recovery phase was 10.7, 7.3 and 10.6. There was small significance between footwear during forward lunge for all coupling joints $(\% \mathrm{P}=4$ for $\mathrm{RHS}$ v.s. FHS, $\% \mathrm{P}=8$ for RHS v.s. SHS and $\% \mathrm{P}=12$ for FHS v.s. SHS). Meanwhile, the significance of VCRP was also small during recovery backward $(\% \mathrm{P}=4$ for RHS v.s. FHS, $\% \mathrm{P}=0$ for RHS v.s. SHS and $\% \mathrm{P}=14$ for FHS v.s. SHS).

\section{DISCUSSION}

The present study evaluated the influence of different shoe heel design (RHS, FHS and SHS) on the movement coordination during the entire lunge movement (forward and recovery backward phases). Through the analysis of higher order variables (PA, CRP and V(RP), the current findings indicated that players wearing RHS had certain advantages on better movement coordination than other shoes, as indicated by better PA and CRP. The findings of this study would be helpful to understand the coordination of badminton lunges and explain the synergy between the lower extremity ankle and knee joint to minimize the possibility of injury in badminton.
Ankle and Knee function during fast lunge could be determined by push-off, initialcontact and foot-flat phases. One interesting phenomenon is that only small variations exist in ankle PA in initial contact of lunge forward. This variation could be comprehended as that the FHS had an apparent pivot point than RHS, and this structure would assist fast ankle plantar flexing. It was also the reason resulting the variations in CRP values. But when considering VCRP, we found that FHS had a higher value than RHS, indicating that coordination was relatively poor. Meanwhile, Kuntze [4] suggested that a peak ground reaction force would be generated while initial contacting and the poor coordination would contribute to a high injury risk. We also found that an earlier ankle plantar flexion occurred in RHS, which implied an earlier forefoot contact and thereby reducing the overall impulse generated in loading response stage [11].

In viewpoint of CRP, a faster initial contact of ankle increased the relative rotation between ankle and knee. The faster relative rotation implies a higher sensitivity of lower limb performance. Sensitivity of lower limbs was highly related with the muscle contraction and relaxation processes, which also reflects the effective movement coordination [4, 15]. Muscle contraction and relaxation are the key processes to movement 
control of badminton lunge, including the posture, velocity and cushioning for ground reaction forces. Therefore, achieving high sensitivity and coordination of lower limb by using different footwear could be beneficial for safety and efficiency in badminton lunge. Our findings about how footwear influences coordination were also consistent with another previous study [21], which suggested the footwear recommendations for RHS, followed by FHS and SHS. Thereby, RHS was a superior choice for lunge movement.

Some experimental limitations should be considered when interpreting our data. First, only left-forward lunge was tested in this study, different lunge directions may induce different coordination strategies. Second, the extreme lunge (i.e., maximum-effort and intensity) was investigated but we did not compare different lunge distances and movement intensities, which may show distinct lunge steps and movement controls. That requires a Hilbert transformation to eliminate the movement coordination. Future investigations should be carried out by comparing different lunge intensities before a viable conclusion about coordination of badminton lunge can be made.

\section{CONCLUSIONS}

Initial contact is the critical phase when investigating badminton lunge. Participants wearing shoes with rounded heel design altered the landing impacts at initial contact. Furthermore, the coordination between the knee and ankle joints was greatly affected by the structure of the shoe heel design. The findings from this study indicate that improving the heel curvature of badminton shoes could be one plausible method to improve movement coordination in badminton.

\section{Acknowledgements}

This work was supported by the National Natural Science Foundation under Grant [31700813]; Sichuan Science and Technology Program under Grant [2020YFH0068]; and the Opening Project of Key Laboratory of Leather Chemistry and
Engineering, (Sichuan University), Ministry of Education.

\section{REFERENCES}

1. Teu, K.K., Kim, W., Tan, J., Fuss, F.K., Using dual Euler angles for the analysis of arm movement during the badminton smash, Sports Eng, 2005, 8, 171-8 https://doi.org/10.1007/BF02844017.

2. Wong, T.K.K., Ma, A.W.W., Liu, K.P.Y., Chung, L.M.Y., Bae, Y.-H., Fong, S.S.M., Ganesan, B., Wang, H.K., Balance control, agility, eye-hand coordination, and sport performance of amateur badminton players A cross-sectional study, Medicine, 2019, 98, 2(e14134), https://doi.org/10.1097/MD.00000000000 14134.

3. Phomsoupha, M., Laffaye, G., The Science of Badminton: Game Characteristics, Anthropometry, Physiology, Visual Fitness and Biomechanics, Sports Med, 2015, 45, 473-495, https://doi.org/10.1007/s40279014-0287-2.

4. Kuntze, G., Mansfield, N., Sellers, W., A biomechanical analysis of common lunge tasks in badminton, J Sports Sci, 2010, 28, 2, 183-191, https://doi.org/10.1080/02640410903428 533.

5. Sorel, A., Plantard, P., Bideau, N., Pontonnier, C., Studying Fencing Lunge Accuracy and Response Time in Uncertain Conditions with an Innovatives Imulator, PLOS ONE, 2019, 14, 7, e0218959, https://doi.org/10.1371/journal.pone.0218 959.

6. Lam, W.-K., Ryue, J., Lee, K.-K., Park, S.-K., Cheung, J.T.-M., Ryu, J., Does shoe heel design influence ground reaction forces and knee moments during maximum lunges in elite and intermediate badminton players?, PLOS ONE, 2017, 12, https://doi.org/10.1371/journal.pone.0174 604.

7. Chen, T.L.-W., Wang, Y., Wong, D.W.-C., Joint contact force and movement deceleration among badminton forward lunges: a musculoskeletal modelling study, Sports Biomech (Epub 2020 Jun 01) 1-13, 
https://doi.org/10.1080/14763141.2020.1 749720.

8. Mehdizadeh, S., Arshi, A.R., Davids, K., Quantifying coordination and coordination variability in backward versus forward running: implications for control of motion, Gait Posture, 2015, 42, 172-177, https://doi.org/10.1016/j.gaitpost.2015.05. 006.

9. Preeti, Kalra, S., Yadav, J., Pawaria, S., Effect of Pilates on Lower Limb Strength, Dynamic Balance, Agility and Coordination Skills in Aspiring State Level Badminton Players, J Clin Diagn Res, 2019, 13, 7, YC1-YC6, https://doi.org/10.7860/JCDR/2019/41713 .12978.

10. Chiu, S.L., Chou, L.S., Effect of walking speed on inter-joint coordination differs between young and elderly adults, $J$ Biomech, 2012, 45, 275-280, https://doi.org/10.1016/j.jbiomech.2011.1 0.028 .

11. Huang, Q., Hu, M., Xu, B., Zhou, J., The coordination of upper and lower limbs in curve-turning walking of healthy preschoolers: Viewed in continuous relative phase, Gait Posture, 2020, 75, 1-7, https://doi.org/10.1016/j.gaitpost.2019.09. 013.

12. Reeves, J., Hume, P.A., Gianotti, S., Wilson, B., Ikeda, E., A Retrospective Review from 2006 to 2011 of Lower Extremity Injuries in Badminton in New Zealand, Sports, 2015, 3, 77-86, https://doi.org/10.3390/sports3020077.

13. Herbaut, A., Delannoy, J., Fatigue increases ankle sprain risk in badminton players: A biomechanical study, J Sports Sci, 2020, https://doi.org/10.1080/02640414.2020.1 748337.

14. Huang, P., Fu, L., Zhang, Y., Fekete, G., Ren, F., Gu, Y., Biomechanical Analysis Methods to Assess Professional Badminton Players' Lunge Performance, JoVE-J Vis Exp, 2019, 148, e58842, https://doi.org/10.3791/58842.

15. Wang, L., Niu, W., Wang, K., Zhang, S., Li, L., Lu, T., Badminton players show a lower coactivation and higher beta band intermuscular interactions of ankle antagonist muscles during isokinetic exercise, Med Biol Eng Comput, 2019, 57, 2407-2415, https://doi.org/10.1007/s11517-01902040-8.

16. Kesilmis, I., Akin, M., Can Kangoo Jump Shoes Effect Plantar-Dorsiflexion Strength and Dynamic Balance Ability of Badminton Players?, Int J Appl Exerc Physiol, 2019, 8, 4, 13-20, http://www.ijaep.com/index.php/IJAE/arti cle/view/561.

17. Hong, Y., Wang, S.J., Lam, W.K., Cheung, J.T.M., Kinetics of badminton lunges in four directions, J Appl Biomech, 2014, 30, 1, 113-8, https://doi.org/10.1123/jab.20120151.

18. Yen, H.C., Chen, H.L., Liu, M.W., Liu, H.C., Lu, T.W., Age effects on the inter-joint coordination during obstacle-crossing, $J$ Biomech, 2009, 42, 2501-2506, https://doi.org/10.1016/j.jbiomech.2009.0 7.015 .

19. Lamb, P.F., Stöckl, M., On the use of continuous relative phase: review of current approaches and outline for a new standard, Clin Biomech, 2014, 29, 484-493, https://doi.org/10.1016/j.clinbiomech.201 4.03.008.

20. Ippersiel, P., Preuss, R., Robbins, S.M., The Effects of Data Padding Techniques on Continuous Relative-Phase Analysis Using the Hilbert Transform, J Appl Biomech, 2019, 35, 247-255, https://doi.org/10.1123/jab.2018-0396.

21. Weir, G., Wyatt, H., Van Emmerik, R., Trudeau, M.B., Willwacher, S., Brüggemann, G.-P., Hamill, J., Influence of neutral and stability athletic footwear on lower extremity coordination variability during a prolonged treadmill run in male rearfoot runners, Eur J Sport Sci, 2019, https://doi.org/10.1080/17461391.2019.1 670867.

(C) 2021 by the author(s). Published by INCDTPICPI, Bucharest, RO. This is an open access article distributed under the terms and conditions of the Creative Commons Attribution license (http://creativecommons.org/licenses/by/4.0/). 